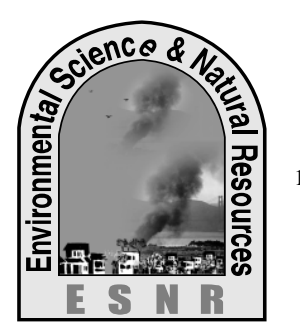

\title{
A Basic Study on Production Performance of Local Cows under a Typical Village Condition of Mymensingh District
}

\author{
M .A. Hossain ${ }^{1 *}$, M. A. Hashem ${ }^{2}$ and M. A. S. Khan ${ }^{1}$
}

${ }^{1}$ Department of Dairy Science, ${ }^{2}$ Animal Science, Bangladesh Agricultural University, Mymensingh *Corresponding Author: anwar.kbd82@gmail.com

\begin{abstract}
The present piece of research work was conducted to find out the present condition of native cattle rearing, milk production and reproductive parameters and to give important suggestion for production constraints. The experiment was conducted at a nearby village named Boira adjacent to Bangladesh Agricultural University, Mymensingh having eighty three local cows and seventeen heifers were taken under this study from 72 farmers selected with direct interview. Data was compiled statistically only for tabular, percentage, mean and standard deviation. Body weight and condition score of the observed value were $173.23 \pm 32.03 \mathrm{~kg}$ and 2.55 \pm 0.34 , respectively. Average daily intake of feed was $12.5 \mathrm{~kg}$ (fresh basis) and $7.72 \mathrm{~kg}$ (DM basis). From the results of experiment, it was found that average daily milk yield of the indigenous cows for whole lactation period was $1.43 \pm 0.58 \mathrm{~kg}$. The mean value of hemoglobin, packed cell volume and fat percentage was $7.8 \pm 1.00\left(\mathrm{~g} 100 \mathrm{ml}^{-1}\right), 52 \pm 52.10(\%)$ and $57.6 \pm 9.1 \mathrm{~g} / \mathrm{kg}$, respectively. Age at first calving for local cows found $52.8 \pm 13.32$ months and calving interval was 417.6 \pm 109.5 days. Birth weight of the local calves found $14.43 \pm 2.56 \mathrm{~kg}$. Average number of eggs of parasite was 53 per gram of feces. From the study it can be concluded that morphometrics, production and reproduction traits of indigenous cows was favorable and profitable practice in selected areas.
\end{abstract}

Key words: Basic study, Local cows, Production performance and Village condition

\section{Introduction}

Livestock plays an important role in Agriculture as well as in national economy in Bangladesh. Our present government has taken a massive long-term program for poverty alleviation throughout the country especially rural people by their own fund and foreign aid. Many Government departments, Board, Autonomous body and Non Government Organization (NGO) are amalgated in this program. Cattle are the valuable components of livestock sector in Bangladerh. Dairying is a biological efficient system that converts large quantities of inedible roughage to milk, the most nutritious food known to man. Milk is renowned as an "almost complete" as well as natural nutritious food for all mammals including human being (Debnath et al. 2014) It is a more efficient and intensive system in term of nutrient and protein production for human consumption.

Despite being an important sector in Bangladesh agriculture, its contribution to the agricultural GDP is much less than those of crop agriculture and fisheries. The contribution of animal farming has remained largely stagnant with a share of around 13 per cent of agricultural GDP over the last two decades. A disaggregated picture, however, shows satisfactory growth for poultry (over 4.5 per cent), followed by goats/sheep (around 4 per cent) in recent years. According to the estimate of the Department of Livestock Services, the present population of cattle, goat, buffalo and poultry is about 23.44 million, 25.61 million, 1.45 million and 307.47 million, respectively in 2012-13 (DLS, 2014). Livestock Department's available statistics show that the domestic production of milk, meat and egg are 3.74, 3.02, and 6745.28 million tons in the fiscal year 2014 against the demand of $14.55,3.77$, and 7544.67 million tons in 2015-16 fiscal year, respectively (Hossain and Hassan, 2013). It has been reported that in the Year 2007-08, it is evident that there is a deficit of (80\%) in milk, $82 \%$ in meat and $63 \%$ in eggs in Bangladesh (FAO, 2008). Cattle of Bangladesh can be classified into two categories (1) indigenous and (2) cross bred. Average live weight of indigenous cow is about $123 \mathrm{~kg}$ and cross bred is about $137 \mathrm{~kg}$ (Islam et al., 2010).

The livestock sector has received little priority in overall government development plans. Less attention has been placed by the policy makers to livestock sector compared to the crop sector, primarily because of the poor state of knowledge about methods and problems of production and utilization of livestock in the country (Jabber and Green, 1983).

People of our country are rearing their cows using traditional methods. They have very little knowledge about the scientific methods of rearing cattle. In order to improve the livestock production at first we have to know the details of our livestock.

Our local cows are the resource of our country. Their milk quality is very good. Their hides and skin quality is better than that of exotic breeds. Local cows are easy to handle, easy to management; feed cost is low, more resistant to disease and more economic than exotic cattle.

Before planning we should know the morphometrics characterization, production and reproduction traits of livestock throughout the country. At the same time present rearing system of livestock in rural areas and also their present production characteristics are needed to be monitored. In this connection the available data on livestock in this country are not sufficient compared to crop statistics. We have very limited information on the production performance of different types of dairy cows available in Bangladesh. In this connection the present piece of study was undertaken with following objectives: To know the present management condition of local cows, To know the present production level of 
local cows and to know the present reproductive status of local cows.

\section{Materials and methods}

\section{Management of cattle site}

One typical village named Boira which is about two kilometer away from Bangladesh Agricultural University; Mymensingh Campus had been chosen and selected for this trial. The villagers are mostly resource poor farmers (small holder farmers). And $22 \%$ of them were landless but every family has some indigenous cattle. The village was well communicated from the University; the farmers were really cooperative and much interested for this type of study. Constant visit and collection of data from farmer's level was easy and possible as better communication exists between the village and University campus. The cows of villagers are generally used for multi purpose such as dairy, draught and meat. Rice straw was the main source of the animals as residual part of crop. Very little roadside green grass used as succulent feed. Wheat bran, oil cake and common salt were fed to the animals by the comparatively better off farmers. Animals are mainly stall feed and sometimes tethered.

\section{Number of animals in study}

Seventy two individual farmers having totaled 83 indigenous cows and 17 indigenous heifers were taken for this study. Baseline data were collected having 100 animals through direct interviewing with 72 farmers. The animals received as usual feed supplied by the farmers of that area on the basis of availability.

\section{Productivity and fertility indices}

Cows were milked once in the morning. Calves were usually tied up at night and they had free access to their dam during the whole day .Productivity had been monitored by supplied International Atomic Energy Agency (IAEA) draft data sheets for measurement of milk production and changes in live weight, condition score (1-5) and from various reproductive indices e. g. at first parturition, interval between parturition and start of sexual cycle/conception, conception rate, number of calves boned/ weaned etc.

\section{Scheduled visits and Sampling}

Eighty three cows and 17 heifers had already been chosen for this trial and had been ear tagged (1-100) for identification. The cows, calves, heifers and milk yield were weighed daily. Details on the variations in ambient temperature and rainfall were recorded from Bangladesh Agricultural University meteorological station. Fecal eggs were examined for parasitism from the collected fecal sample of individual animal.

\section{Methods of Feeding}

Cows were fed as usual traditional system by the villagers. Most of the animals were mainly stall fed and sometimes tethered. Determination of Dry matter, crude protein $(\mathrm{CP})$ and Ash were done according to AOAC (1984) in the laboratory of the Department of Animal Nutrition. RDP, UDP, digestibility of CP and DM were done according to Scottish Agricultural College bulletin (1984).

\section{Condition Score and Daily Milk Yield}

Body condition of the cows had been estimated monthly. Scottish Agricultural College grading i. e. 1-5 had been used for this purpose. Our indigenous cows score ranges are between 2.0 to 3.0. Milk yield of individual cows were recorded daily.

\section{Statistical Analysis}

The study was data base type experiment but not trial type experiment. The data was not compiled in design of experiment. Analysis was done mainly through tabular and statistical analysis such as percentages, mean and standard deviation etc.

\section{Results and Discussion}

\section{Physical and morphometric characteristics in indigenous cattle}

Table 1. Summary of base line information for cows, calves and heifers

\begin{tabular}{|l|l|}
\hline Parameters (No. of cows:100) & Mean \pm SD \\
\hline Body wt. of cows (kg) & $173.23 \pm 32.03$ \\
Heart girth of cows (cm) & $131.50 \pm 7.85$ \\
Condition score of cows & $2.55 \pm 0.34$ \\
Milk yield per day (liter) & $1.43 \pm 0.58$ \\
Milk fat(g kg ${ }^{-1}$ ) & $57.6- \pm 9.1$ \\
Milking per day & $1.00 \pm 0.00$ \\
Age at first calves (month) & $52.80 \pm 13.32$ \\
Interval between calving (days) & $417.60 \pm 109.50$ \\
Age of cows (year) & $6.83 \pm 1.74$ \\
No of parity & $2.11 \pm 0.93$ \\
Birth wt. of calves $(\mathrm{kg})$ & $14.43 \pm 2.56$ \\
Age of calves (days) & $30.33 \pm 17.01$ \\
Body wt. of calves $(\mathrm{kg})$ & $18.29 \pm 7.34$ \\
\hline No. of heifers=17 & Mean $\pm \mathrm{SD}$ \\
\hline Age of heifers (year) & $2.79 \pm 0.53$ \\
Body wt. of heifers $(\mathrm{kg})$ & $151.25 \pm 31.06$ \\
Heart girth of heifers $(\mathrm{cm})$ & $126.25 \pm 12.21$ \\
\hline
\end{tabular}


Initial baseline data along with laboratory analysis has been summarized from 83 cows, their calves and 17 heifers which are mentioned in Table 1 . Average body weight of the local cows was $173.23 \pm 32.03 \mathrm{~kg}$. Ahmed (1995) observed the average body weight of local cows under village condition was 167.21 23.08 . Khan and

The observed heart girth of the local cows was $131.50 \pm 7.85 \mathrm{~cm}$ and rage was $123.65-139.35 \mathrm{~cm}$. There was positive correlation within body weight, condition score and heart girth. Body weight directly influences the heart girth. Condition of body status and health of animal may influence this factor. Size of animal partially influences the heart girth.

Birth weight of local calves was found $14.43 \pm 2.56 \mathrm{~kg}$. Hossain and Routlege (1982) reported that the birth weight of Pabna milking cows' calves was $16.37 \pm 2.20$ $\mathrm{kg}$. So within the breed selection of individual superior sire could be an important factor in term of improving birth weight of calves. The means for body length, height at wither, heart girth, pouch girth, length of tail, switch, neck, ear and head were 83.668 \pm 0.590 , $91.942 \pm 0.55, \quad 113.146 \pm 0.738, \quad 121.181 \pm 0.761$, $54.196 \pm 0.527, \quad 26.098 \pm 0.186, \quad 32.705 \pm 0.166$, $18.131 \pm 0.111$ and $35.035 \pm 0.195 \mathrm{~cm}$, respectively (Kayastha et al., 2011). There are several factors which influence the birth weight of calves e.g. genetic background is the most important among them. Nutritional status of pregnant dam and body condition also has remarkable effect on this trait. Sex of calf,
Hossain (1994) reported that the local cows' body weight was $174.13 \pm 31.18 \mathrm{~kg}$. A number of factors may influence the age of body weight. Genetic make up is the main factor which influences this factor. Balanced nutrition, environmental condition, parasitic infestation, care and management may also affect body weight. twining and season of birth also affect the weight of calves.

The observed condition score of local cows was $2.55 \pm 0.34$ and range was 2.0-3.0. There was a positive correlation between condition score and body weight. Environmental condition directly influences condition score. Season and weight of the animal may also influence this factor.

\section{Productive and reproductive traits Chemical composition of feed}

From table 2, in the analysis of village level feed that sesame oil cake contains highest amount of DM and lowest amount in green grass. Sesame oil cake also contains highest amount of CP ( $\left.\mathrm{gkg}^{-1} \mathrm{DM}\right)$ and lowest in rice straw. In $\mathrm{Dg}$ of $\mathrm{DM} \%$ sesame oil cake contain lowest amount and highest in wheat bran. UDP and RDP in sesame oil cake found highest and lowest in rice straw. Ash contain highest in rice straw and lowest in green grass. Taher et al. (2002) reported that the DM and CP of rice straw and wheat bran were $910 \& 890$ and $121 \& 131 \mathrm{gkg}^{-1}$ respectively. Pathol (1994) reported that the DM and CP of sesame oil cake were 900 and $370 \mathrm{gkg}^{-1}$ respectively.

Table 2. Chemical composition of the village level feed

\begin{tabular}{|l|l|l|l|l|l|l|l|}
\hline Feed ingredients & \multicolumn{6}{|l|}{ Average composition of the village level feed } \\
\hline & $\begin{array}{l}\text { DM } \\
\mathrm{gkg}^{-1}\end{array}$ & $\begin{array}{l}\text { Ash } \\
\mathrm{gkg}^{-1}\end{array}$ & $\begin{array}{l}\text { RDP } \\
\mathrm{gkg}^{-1} \\
\mathrm{DM}\end{array}$ & $\begin{array}{l}\text { UDP gkg } \\
\text { DM }\end{array}$ & $\begin{array}{l}\text { CP } \\
\mathrm{gkg}^{-1} \\
\mathrm{DM}\end{array}$ & $\begin{array}{l}\text { Digestibility } \\
\text { of CP\% }\end{array}$ & $\begin{array}{l}\text { Digestibility of } \\
\text { DM\% }\end{array}$ \\
\hline Rice straw & 850 & 140 & 40 & 13 & 53 & 75 & 39 \\
\hline Green grass & 200 & 58 & 52 & 20 & 72 & 72 & 71 \\
\hline Wheat bran & 875 & 69 & 114 & 40 & 154 & 71 & 84 \\
\hline Sesame oil cake & 890 & 133 & 197 & 114 & 311 & 62 & 8 \\
\hline
\end{tabular}

\section{Feed Intake of cow at Village Level}

Daily feed intake has been measured at the village level of cows. Table 3 shows the feed intake of village level feed. Measurement of daily intake of feed was not always possible during rainy season due to muddy roads of the village. From table 3, highest amount of DM, $\mathrm{RDP}, \mathrm{UDP}$ and $\mathrm{CP}$ were found in rice straw and lowest in wheat bran (DM) and in road side grass of other composition

Table 3. Average daily intake of feed at the village of indigenous cows

\begin{tabular}{|l|l|l|l|l|l|}
\hline Ingredients & $\begin{array}{l}\text { Fresh wt. } \\
\left(\mathrm{kg} \mathrm{day}^{-1}\right)\end{array}$ & $\mathrm{DM}\left(\mathrm{kg} \mathrm{d}^{-1}\right)$ & $\mathrm{RDP}\left(\mathrm{g} \mathrm{d}^{-1}\right)$ & $\mathrm{UDP}\left(\mathrm{g} \mathrm{d}^{-1}\right)$ & $\mathrm{CP}\left(\mathrm{g} \mathrm{d}^{-1}\right)$ \\
\hline Rice straw & 7.5 & 6.38 & 255 & 83 & 338 \\
\hline Roadside grass* & 4.5 & 0.90 & 47 & 18 & 65 \\
\hline Wheat bran* & 0.5 & 0.44 & 50 & 18 & 68 \\
\hline Total & 12.5 & 7.72 & 352 & 119 & 471 \\
\hline
\end{tabular}

*Optional

\section{Productive parameters}

Average daily milk yield of indigenous cows was $1.43 \pm 0.58 \mathrm{~kg}$. Initial data shows that the average milk production was minimum under present situation. Animals were mainly under feed. Cows in the research area were milked only in the morning i. e. once a day. So, the actual milk production could have been higher than that of present average figure of $1.43 \mathrm{kgday}$. Ali (1994) reported that the milk production varied according to season and area. He conducted the 
experiment on local cattle using data collected from four different areas of Bangladesh and highest milk was observed in winter season (1.93 kg per day). He also found the highest milk yield in Pabna cows $(20.50 \mathrm{~kg}$ per day). Bhuiyan and Faruque (1994) studied the performances of local cows under rural condition and average milk yield was $1.63 \mathrm{~kg}$. There are several factors which influence the milk production of cows such as quality and quantity of feed, ambient temperature, humidity and care of the herd.

The mean fat content of local cow's milk during the whole study period was $57.9 \pm 9.1 \mathrm{~g} \mathrm{~kg}^{-1}$. Little information is available on the fat content of local cow's milk. Hossain (1968) conducted an experiment on indigenous cows of Mymensingh district and found the mean fat content was $46.0 \mathrm{~g} \mathrm{~kg}^{-1}$ of milk. Islam (1990) studied the milk composition of local cows from Manikganj district and found the fat was $46.9 \mathrm{~g} \mathrm{~kg}^{-1}$ of milk. Fat content of local cows were greater than that of exotic and cross bred cows due to straw based diet intake of the local cows. On the other hand, the production of local cows is low. It is said in dairy cattle rearing that maximum milk production contain minimum fat and minimum milk production contain maximum fat. Fat percentage may be affected by the quality of feed, number of lactation, stage of milking, exercise of animals, season of year as well as quantity of milk yield.

Calves were ties up at night and cows were milked once a day early in the morning. Calves were free access for suckling to their dam throughout the day which is good feeling for the farmers for the better health of calves.

\section{Reproductive parameters}

It is revealed from the table 1 that the indigenous cows in the village condition of feeding and management usually show their first reproductive performance late as compared with exotic, pure and cross bred animals. Age at first calving was also high. Age at first calving was calculated from the data of birth to the date of first calving in months. It was found that the age at first parturition of local cows were $52.8 \pm 13.32$ months. Ghosh et al. (1977) studied some reproductive parameters of milking cows and reported that age at first calving for Red Chittagong heifers was 39.96 \pm 3.96 months. On the other hand, Islam and Oliuzzaman (1993) reported that average age at first calving of local cows was $48.72 \pm 7.56$ months. A number of factors may influence the first calving of heifers. Genetic makeup is the main factor which influences this trait remarkably. Level of nutrition supplied during the growing period is another important factor which affects this trait directly. Environmental condition, parasitic infestation, care and management may also affect this trait. Season of birth also have an indirect affect on age at first calving.

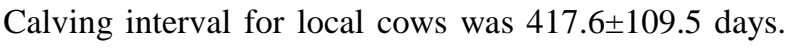
Actual calving interval could have been even earlier of the present average figure of 417 days, because calves sucked the cows which have an effect on the start of estrus cycle of cows after calving which ultimately lengthen the present calving interval. Ghosh et al. (1977) studied the calving interval of locally available dairy cows and observed that calving interval of Pabna, Dhaka and Red Chittagong cows were $489 . .3 \pm 75.6,523.8 \pm 50.1$ and $430.8 \pm 75.0$ days respectively. Rahman et al. (1987) conducted an experiment and found that the calving interval of local, Sindhi and Shahiwal cows were 410.1 $\pm 7.5,441.3 \pm 14.1$ and $446.7 \pm 108.0$ days respectively. Islam and Oliuzzaman (1993) found average calving interval was $525.0 \pm 87.9$ days. Various factors like breed, nutrition, age, parity, milk yield, suckling, year and season may influence the calving interval (Sharma and Singh, 1980). In zebu cattle calving interval ranged from 366789 days (Koul, 1987). Moreover of the animals were infested by parasites and that could be one of the responsible factor for less milk production and poor fertility. Suckling blood and damaged liver cause anemia and abnormal physiology of the body.

No of eggs of Fasciola gigantica was counted by Mc Master Method and found of average no. of eggs were 53 per gram of feces. It has been reported in the literature that parasites usually suck $10-15 \%$ of the host nutrients.

\section{Blood parameters}

Table 4. Result of Blood parameters analysis

\begin{tabular}{|l|l|l|}
\hline Parameter & Range & Mean \pm Sd \\
\hline Hemoglobin $\left({\left.\mathrm{g} 100 \mathrm{ml}^{-1}\right)}^{\text {PCV }(\%)}\right.$ & $6.10-10.20$ & $7.81 \pm 1.00$ \\
& $27-81$ & $52 \pm 10$ \\
\hline
\end{tabular}

\section{Estimate of Hemoglobin}

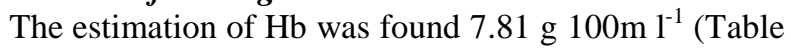
4). In most mammals normal Hemoglobin $(\mathrm{Hb})$ values are between $8-15 \mathrm{~g} \quad 100 \mathrm{~m} \mathrm{l}^{-1}$ (Banerjee, 1988). Excitement may increase not only the Hemoglobin concentration but the PCV and erythrocyte number per unit volume (Swenson, 1977). Kobina et al. (2015) reported that the $\mathrm{Hb}$ concentration was $10.9 \mathrm{~g}^{100 \mathrm{ml}^{-1}}$ of blood where observation cattle were 440. Many researchers reported that $\mathrm{Hb}$ level of blood indicates the deficiency of protein level in food. It was sure that ration was not properly balanced; the animals were suffering from mal nutrition and anemia. As a result hemoglobin level drops from normal level

Determination of Packed Cell Volume (PCV) 
The PCV percentage of the local cows was found 52 and range was $27-81 \%$ (Table 4). PCV values fall in early lactation as milk yield rises then tends to rise as lactation progresses. Kobina et al. (2015) reported that the PCV value was $28 \%$ of blood where observation cattle were 440. However, values are often low in late winter but recover when cows go out to pasture. Values are highest in summer but in many circumstances high level may be indicative of dehydration. Sometimes this can be due to a reduced water intake which may caused by social drinking. The observed value of PCV percentage was high. It is clear to identify that the local cows were not supplied sufficient fresh drinking water.

\section{Conclusions}

In conclusion, above reveals that there are marked differences of performance of indigenous cattle regarding morphometrics characterization, productive and reproductive traits in selected area as well as throughout the whole areas of Bangladesh..These characterizations might be helpful for research and extension peoples for further relevant studies.

\section{References}

A.O.A.C. 1984. Official Method of Analysis, (14 ${ }^{\text {th }}$ Edition.) Association of Official Analytical Chemists. Washington, D.C. U. S. A.

Ahmed, A. R. 1995. A baseline Study on Production Performances of Zebu Cattle of Supplementation Strategies in Bangladesh. MS Thesis, Department of Dairy Science, Bangladesh Agricultural University, Mymensingh.

Ali, M. 1994.Evaluation on Livestock Resources and Performances of indigenous lactating cows on rice straw based in ration of Bangladesh. Ph.D. thesis. Faculty of Graduate School University of Philippine at Los Banos, Philippine

Ali, Z. and Hossain, I. 2014. Barriers to the development of livestock sector in Bangladesh. Bangladesh Institute of Development Studies, Policy brief., 408: 1-8.

Banerjee, G. C. 1988. Feeds and Principle of Animal Nutrition. Revised Edition. Pp.68-69, 608 Oxford and I. B. H. Publishing Company Private Limited, New Delhi.

Bhuiyan, A. K. F. H. and Faruque, M. O. 1994. Yield and variability of milk production of the local cattle of Bangladesh. Bangladesh Agricultural University Research Progress, 8: 440 - 443.

D. L. S. 2014. Department of Livestock Services Government of Peoples Republic of Bangladesh.

Debnath, G. K.; Kober, A. K. M. H.; Chanda, G. C.; Chanda, T. and Barious, A. 2014. Comparative study on Quality of available brand and non brand fluid milk consumed by people Chittagong city of Bangladesh. International Journal of Natural Sciences, 4(1): 16-20.

FAO. (Food and Agriculture Organization of the United Nations) 2008. Production Year Book. Rome, Italy.

Ghosh, S. C.; Sadullah, M.; Huq, M. A. and Rahman, M. 1977. A comparative Study of Age at first calving, gestation period and calving interval of different breeds of cattle. Bangladesh Veterinary Journal, 11(1-4): 9-14.

Hossain, A. M. 1968. A study of average percentage of fat, total solids and solid not fat content of local cows, variation of milk fat percentage with the stage of lactation, milk yield and number of lactation. M.Sc. Thesis, Department of Dairy Science, Bangladesh Agricultural University, Mymensingh.

Hossain, M. A. and Routledge, S. F. 1982. Performance of crossbred and local cattle under village condition in Pabna District of Bangladesh. Proceedings of Maximum livestock production from minimum land. Seminar. pp. 161-167.

Hossain, M. J. and Hassan, M. F. 2013. Forecasting of Milk, Meat and Eggs Production in Bangladesh. Research Journal of Animals. Veterinary and Fishery Sciences, 1: 7-13.

Islam, M. A. 1990. A study on the milk yield, composition and energy value of indigenous cows' milk at surrounding village of Manikgonj Milk Chilling Center, Milk Vita, Manikgonj. M.Sc.thesis, Department of Dairy Science, Bangladesh Agricultural University, Mymensingh.

Islam, M. M.; Topaderand, A. H. H. and Rob, A. 2010. Comparative study on the cost benefit between of indigenous and crossbred cows reared in rural area of Dinajpur district. Bangladesh Journal of Animal Science, 39 (1\&2): 191-196.

Islam, M. N. and Oliuzzaman, M. 1993. Existing production practices of indigenous cattle in Mymensingh district. Bangladesh Agricultural University, Research Progress, 7: 340-348.

Jabber, M. A. and Green, D. A. G. 1983. The status and potential of livestock within the context of Agricultural Development Policy in Bangladesh. Aberystwyth, U.K.,University College of Wales. Department of Agricultural Economics (Research report).

Kayastha, R. B. G.; Zaman, R. N. Goswami, and Haque, A. 2011. Physical and Morphometric Characteristics of indigenous Cattle of Assam. Open Veterinary Journal, 1(1): 7-9.

Khan, M. A. S. and Hossain, M. A. 1994. Study of baseline information for the effect of UreaMolasses Block (UMB) without or with by-pass Protein source in straw based diet on the performances of indigenous cows and heifers. Bangladesh Agricultural University Research Progress. 8: 404-409.

Kobina, P. T.; Ebenezery, and Ganyo, 2015. Relationship between Hemoglobin concentration and Packed Cell Volume in cattle blood samples. Journal of Veterinary Research, 82(1): 5.

Koul, G. L. 1987. Age at first calving, calving interval and their relation to milk yield in Haryana cattle. Indian Journal of Dairy Science. 40(2): 169-173.

Kumer, S.; Mole, S.; Sing, D.; Chauhan, S. S. and Ghosh, N. 2014. Effect of environmental factors on lactation yield and lactation length of Holdeo 
crossbred cattle. Indian Journal of Applied Researc., 4(10): 4-7.

Nahar, T. N.; Islam, M. and Hasnath, M. A. 1992. A comparative study on some Productive and Reproductive Performances of Dairy Cow. Dairy Cattle Improvement Farm, Savar. Bangladesh Veterinary Journal, 21(1-2): 55-61.

Pathol, J. C. 1994. Enzymes Degrading Agro Industrial Residues and their production. Journal, 47(1):78-79.

Rahman, M.; Ahmed, N. and Ahmed, A. R. 1987. A comparative study on some Productive and Reproductive performances of Dairy Cows, Dairy Cattle Improvement. Bangladesh Veterinary Journal, 21(1\&2): 55-61.

Sarma, N. C. and Singh, B. C. 1980. Factors affecting calving interval in cross- bred cows. Indian Veterinary Journal, 63: 317-317.

Scottish Agricultural College. 1984. .Nutritional Allowances for Cattle and Sheep. Scottish Agricultural Publication, pp. 29.

Swenson, M. J. 1977. Duke Physiology of Domestic Animals. Ninth Edition, pp. 22-28, Comstock Publishing Associates, Ithaca and London

Taher.; Khaleque, M. A.; Pasha, T. N. and Bhatti, J. A. 2002. Comparative evaluation of Maize bran, Wheat bran and Rice bran on Milk Production of Holstein Friesian cattle. International Journal of Agriculture and Biology, 4(4). 